\title{
NOTES ON MYXOMYGETES IV \\ MYXOMYCETES COLLECTED IN THE NETHERLANDS, GHIEFLY IN THE VICINITY OF DOORWERTH (GELDERLAND)
}

\author{
N. E. NANNENGA-BREMEKAMP \\ (Doorwerth)
}

(received September 6th, 1960)

This is the first of a series of short papers dealing with Myxomycetes collected by me since August 1951 in the Netherlands, mostly in an area not exceeding 6 square kilometers in extent, situated round Doorwerth in the province of Gelderland, and extending from Heelsum in the West to Oosterbeek in the East, and from Wolfheze in the North to the banks of the Rhine in the South. Localities will only be mentioned by name when the specimens were collected outside this area, or when they appear to be rare here.

Species which according to Prof. Dr. W. K. H. Karstens (private communication) have not been found previously in the Netherlands, have been marked with an asterisk. The (unpublished) list of Dr. Karstens, which covers the whole of the Netherlands, contains 18 species that were not found by me.

Specimens of all species included in my list are preserved either in my private collection or in that of the Botanical Museum and Herbarium of the State University, Utrecht (in the last-mentioned case the number is followed by a " $U$ ") or in both.

I would like to thank the Keeper of Botany of the British Museum of Natural History, London, for allowing me to study the Lister collection, and the staff of the Cryptogamic Department of the British Museum for their kind help. I am also indebted to Dr. D. A. Reid and Dr. R. G. Dennis of the Kew Herbarium for their assistence during my visit to that Institute, and especially to Prof. Dr. G. W. Martin for his help and critical remarks, and for the exchange of named specimens, and to Prof. Dr. W. K. H. Karstens for his advice and for the permission to use the above mentioned list, which comprises all Myxomycetes that were known to him from the Netherlands up to 1953. After that date very little has been added by other authors to our knowledge of the Netherlands Myxomycetes.

\section{Ceratiomyxa Schröt.}

Ceratiomyxa fruticulosa (Müll.) Macbride.

Very common on decaying wood $(11,107 ; 172 ; 238 ; 249 ; 283 \mathrm{U} ; 610 ; 683$; $954 \mathrm{U} ; 976 ; 986 ; 1166 ; 1183 ; 1283 ; 1233$ v. infra; $1861 \mathrm{U} ; 1884 \mathrm{U} ; 1894 \mathrm{U}$; 1896; 1909; 1910; 1921, "var. flexuosa" v. infra; 1957 U; 1976; 2000 U; 2043 U; $2116 \mathrm{U} ; 2131 ; 2219 ; 2570 ; 2575$, "var. flexuosa" v. infra; 2583; 2622/3, "var. fexuosa" v. infra; $2628,2629 \mathrm{U} ; 2639 \mathrm{U} ; 2681: 2801 \mathrm{U} ; 2816 \mathrm{U} ; 2862 \mathrm{U} ; 2870 \mathrm{U}$; $2872 ; 2993 ; 3033 ; 3069 ; 3731 ; 3981 \mathrm{U} ; 4171 \mathrm{U} ; 4243)$.

Very variable in shape: almost simple to intricately branched, the branches sometimes reticulately anastomosing; in the sporophores: from flat and rather broad to slender, white, pale ochraceous or 
salmon-coloured, with a more or less prominent areolation, and practically without granules or with a rather large number of granules in scattered groups; in the spore stalks: terete (round in optical section) or flattened (oval in optical section); and in the spores: usually prolate, but sometimes subglobose, smooth or with minutely granulate contents (in 1233 coarsely granulate, v. infra).

Quite a number of varieties have been described in this species. The numbers 1921, 2219, 2575, 2622, 2623 and 2801 answer the description of var. flexuosa Lister, but it seems to me that this variety can not be kept up as intermediate forms occur.

It is perhaps of interest to note that the spore stalks or spicules, the connection between the spore and the sporophore, differ in length. In the monographs published by the Listers, by Macbride and Martin and by Hagelstein no attention is paid to their length, but in the "North American Flora" Martin calls them "slender" and "uniform", in contrast to those of $C$. sphaerosperma Boedijn, where those at the tip of the sporophore branches are said to be several times as long as the lateral ones. In all specimens of $C$. fruticulosa collected by me part of the spore stalks are two to four times as long as the others (Fig. 1 a, b and c), and these longer ones are scattered over the whole sforophore.

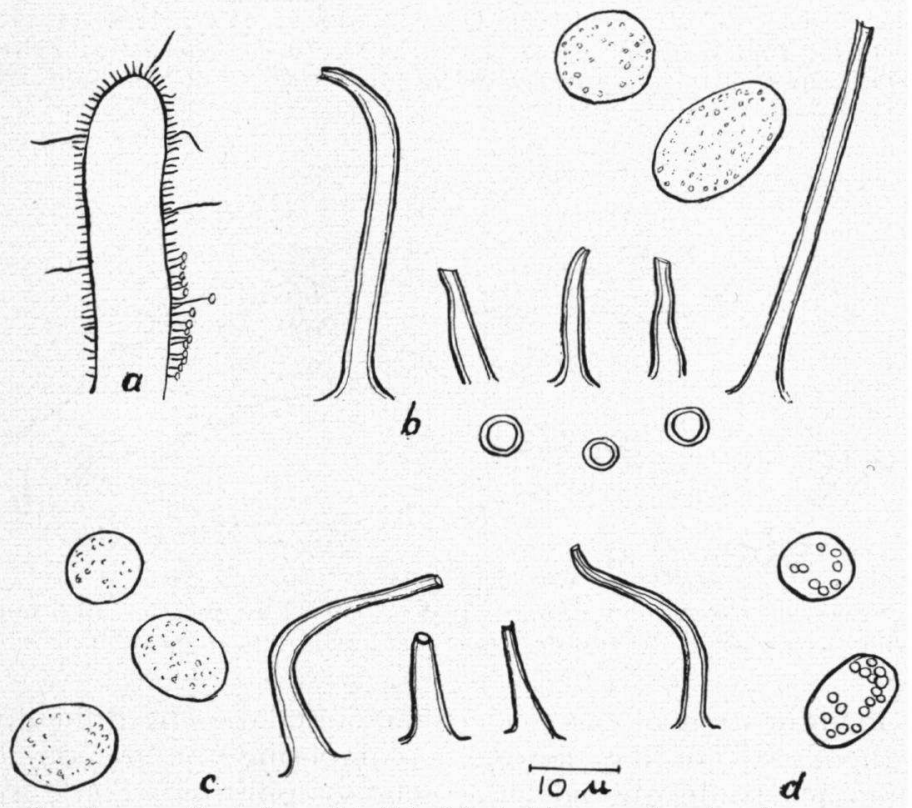

Fig. 1. Ceratiomyxa fruticulosa (Müll.) Macbride: a. sketch of a sporophore in longitudinal section, showing length and distribution of spore stalks; b. spore stalks (three seen from above) and spores (4368) in entirely fresh (moist) condition; c. the same after a few hours of gentle drying; d. spores of 1233 .

In 1233 the contents of the spores are not smooth or very minutely granulate, but coarsely granulate or warted (Fig. $1 \mathrm{~d}$ ). Part of this 
specimen was sent to Dr. Martin, who kindly studied it for me, and suggested that the difference might be due to the spores not being perfectly mature. In view of the large number of specimens in which no spores of this kind were found, this did not look very probable to me, but as the possibility could not be excluded, it seemed advisable to study the spores of sporangia in different stages of development. To this end large plasmodia of Ceratiomyxa were collected, and placed in a moist chamber. At different stages parts were taken out and left to dry. The result was that in none of the different samples (i.e. in 3981 with white sporophores, and in 4243 with salmoncoloured ones) spores were found that resembled those of 1233; they were all of the ordinary kind, i.e. with finely granulate contents. Even spores that were taken from a still moist and transparent sporophore proved to be indistinguishable from those found in a fully mature part. It seems probable, therefore, that 1233 is different, but as the difference seems to be confined to this point, it does not seem worth varietal distinction.

Tubifera J. F. Gmel.

Tubifera ferruginosa (Batsch) J. F. Gmel.

Mostly on dead stumps of coniferous trees $(18 ; 66 \mathrm{U} ; 147 ; 175 \mathrm{U}$, collected at Bilthoven; $191 \mathrm{U} ; 321 \mathrm{U}$; 430; $565 \mathrm{U} ; 742$; 1015; 1150; 1250; 1311; 1569; $1981 ; 2012 \mathrm{U}$; 2021 U; 2114; 2393; 2755; 2790; 2878, collected at Zeist; 2998; 3003 ; 3496$)$; more rarely on dead wood of other trees (93 U, on Salix; 2021, on Betula; 3153, on Prumus).

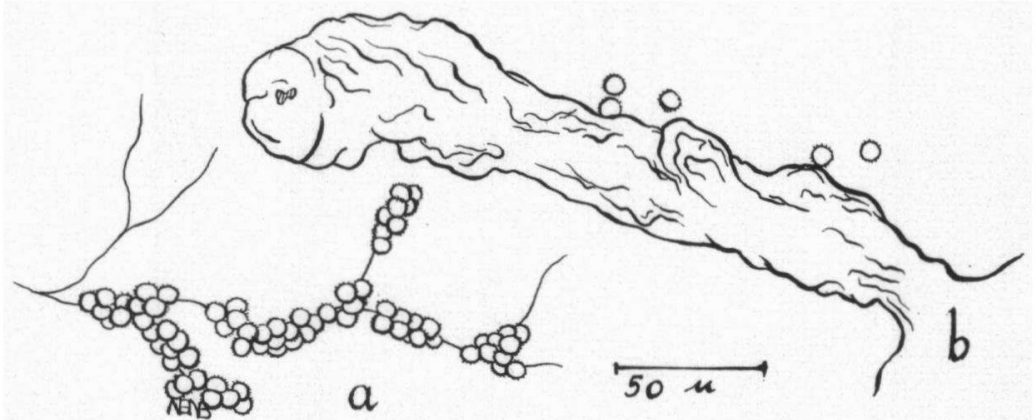

Fig. 2. Tubifera ferruginosa (Batsch) J. F. Gmel.: a. pseudo-capillitium with adhering spores (93); b. tubule projecting inward from peridium (4135).

The identification of these specimens offered some difficulties. In all of them part of the sporangia composing the pseudo-aethalia contain either slender threads of a pseudo-capillitium (Fig. 2 a), rigid tubuli suspended from the peridium (Fig. 2 b), or columellae; sometimes two of these structures are present in the same pseudo-aethalium, and occasionally even all three. The structure of the pseudo-aethalium itself varies too. In a large number of specimens the sporangia are entirely free in the upper half, and closely appressed in the lower one. On account of the presence of the pseudo-capillitium and columellae 
identification with the keys given in the monographs of the Listers, of Macbride and Martin and of Martin would lead to their inclusion in $T$. casparyi (Rost.) Macbride, as in that species pseudo-capillitium is present, and as in about a third of the sporangia composing the pseudo-aethalium columellae are found, whereas $\boldsymbol{T}$. ferruginosa is said to be "destitute of any trace of columella and capillitium". However, in a specimen probably collected in Iowa and identified by Macbride, of which Dr. Martin kindly sent me a part, a few slender threads of pseudo-capillitium are present, so that the absence of the latter can not be regarded as a general character.

Another difference between the two species is said to be found in the size of the spores. According to Macbride those of T. casparyi measure $7.5-9 \mu$ in diam., whereas those of $T$. ferruginosa are 6-8 $\mu$ in diam.; those of $\mathcal{T}$. casparyi, moreover, are said to be darker and more thoroughly reticulate. This difference in the surface of the spores is not mentioned by Martin in the "North American Flora", where the spores of both species are described as "reticulate over three-fourth of the surface". C. J. Alexopoulos (in Brittonia 10: 27. 1959) describes the spores of two Greek specimens of $T$. ferruginosa as "more uniformly reticulate than is usual for the species", while K. S. Thind and M. S. Manocha (in Indian Phytopathology 11: 19-20. 1958) describe a specimen from the Mussoorie Hills as having the spores $5.2-6.4 \mu$ in diam.; as no mention is made of a capillitium, the latter was presumably absent, as according to the literature, it should be.

In my specimens the spores look exactly like those figured by Lister for $T$. casparyi, i.e. they are practically all of them reticulate for about seven eighths of their surface, the remaining part being brokenly reticulate, or reticulate with wider meshes; in size they agree, however, with those of $T$. ferruginosa, for they are 6.5-8 $\mu$ in diam.

In the Lister collection I could study two specimens identified as T. casparyi (B.M. 2805, from Sweden, and B.M. 2806, from Washington). The spores proved to be about $8 \mu$ in diam., and the peridium was papillate in the first-mentioned specimen, and nearly smooth in the second. The specimen from Washington, moreover, had the columellae branching at the tip. All in all the difference between these specimens and $T$. ferruginosa is not very marked. However, I did not see the specimen shown in Fig. 150 of Lister's monograph, which looks rather distinct, for it shows regular horizontal connections between peridium and columella, and this should probably be regarded as an important character. If the specimen figured by Lister, which was collected in the United States, really belongs to the species described by Rostafinski, it must be regarded as excluded that the specimens collected in the Netherlands could belong to the latter.

According to Macbride and Martin (Monograph) other differences are found in the peridium and in the hypothallus. The former would be minutely granular in $T$. casparyi, and thin and transparent in 
$T$. ferruginosa; Lister, however, mentions in $T$. ferruginosa the presence of warts or papillae on the inner surface of the peridium, but gives no information on the structure of the peridium in $T$. casparyi; in my specimens smooth, warted or papillose peridia are present. The hypothallus is described as strongly developed, white and spongiose in $T$. ferruginosa, and as thin, brown and explanate in $T$. casparyi; in my own specimens they are spongiose, never extending beyond the aethalium. The structure of the hypothallus may prove to be the best diagnostic feature to separate the two species.

Another difference between the two species lies in the colour of the plasmodium. That of $T$. ferruginosa is described by all the abovementioned authors as passing through a beautiful rose colour, whereas that of $T$. casparyi apparently does not show this bright hue, but is described as white changing into a dull grey, and finally becoming umber.

In a quite considerable part of the specimens collected by me, the development of the pseudo-aethalia out of the plasmodium could be studied, and in all of them the latter appeared to pass through a stage in which it showed a bright orange or salmon colour. For this reason too it seemed to me that they ought to be referred to $T$. ferruginosa. This conclusion seems to be confirmed by the fact that the peridium is either smooth or papillate, but never granular, as that of $T$. casparyi is said to be. It must be admitted, however, that this character is perhaps not fully reliable, as in the two specimens of the Lister collection that were studied by me, the peridium was not granular either.

The spores in my material measure $6.5-8 \mu$ in diam., and this too is in agreement with the descriptions given of $T$. ferruginosa, but as there is some overlapping in the size of the spores, this character can not be regarded as decisive.

The greatest difficulty is caused by the fact that some of my specimens have columellae and a liberal amount of pseudo-capillitium, in fact 93 looks quite woolly inside, but it seems to me that the variability in respect to this character may be greater than hitherto has been assumed. Therefore, unless we place ourselves on the standpoint that a larger number of species has to be distinguished in this group, and for this standpoint there seems to be no sufficient ground as yet, it seems best to include our material in $T$. ferruginosa.

Macbride and Martin mention the occurrence of a membrane covering the pseudo-aethalia of $T$. casparyi. Among my own collections 1311,2755 , and part of one of the four aethalia of 2012 show a broken film, not unlike the one which covers the aethalium of Reticularia. This, and the presence of the slender Reticularia-like pseudocapillitium, seem to point to an affinity of Tubifera with the Reticulariaceae, rather than with the Liceaceae, where this genus is placed by Martin in the "North American Flora". Tubifera is doubtless related to Alwisia, which was included by Martin in the Reticulariaceae. It has a similar pseudo-capillitium as Tubifera, but its sporangia, though connected at the base in a common stalk, are free. 
However, in some specimens of Tubifera the sporangia are also nearly free.

In my opinion the delimitation of the family Reticulariaceae ought to be widened so as to include the genera Alwisia, Tubifera, Dictyaethalium, Enteridium and Lycogala. It would then be characterized by sporangia combined into aethalia or pseudo-aethalia and, at least, provided with a common stalk, by the structure of the but rarely lacking pseudo-capillitium, and in that of the outer covering.

The strong resemblance between Alwisia and Tubifera has already been pointed out, that between Tubifera and Dictyaethalium is also very striking, the main point of difference being that in Dictyaethalium the walls between the sporangia have disappeared for the most part. Reticularia resembles Tubifera in the structure of the pseudo-capillitium and in some cases in that of the cortex, and Enteridium shows a very near affinity with Reticularia. The tubules which in Lycogala replace the threadlike pseudo-capillitium found in the other genera, occur side by side with the latter in Tubifera.

\section{Craterium Trent.}

The genus Craterium is represented in my collection by five species from the Netherlands, four from the vicinity of Doorwerth, and one from Bilthoven (prov. of Utrecht). Two species and one variety are new records for the Netherlands, and one (Cr. concinnum) was apparently not yet recorded from Europe.

Craterium minutum (Leers) Fries.

On dead leaves and straw (193 U; $198 \mathrm{U}$; $329 \mathrm{U} ; 369 \mathrm{U} ; 377 ; 383 \mathrm{U}$; 398; $634 ; 711 \mathrm{U} ; 740 \mathrm{U}, 978 ; 1295 ; 1302 ; 1369 ; 1395$, Bilthoven; $1750 ; 1825 ; 1855$; $1862 ; 2268 ; 2274 ; 2317 ; 2353 ; 2960 ; 3085 ; 3150 ; 3184 ; 3288 ; 3294 ; 3304$ U).

The cup as well as the stalk always show a bright yellow to orange tint by transmitted light. Occasionally in some of the sporangia belonging to the same colony the cups are confluent $(377,3288$, 3298 ), and with one exception (part of 1855) the lid is well defined; in the aberrant part of 1855 the lid is absent, and here the sporangia dehisce irregularly at the top, but in other sporangia of this colony the lid is normally developed. The spores show but little variation, and this is observed in the other species of this genus too. The plasmodium is bright vermillion or orange.

\section{* Craterium concinnum Rex.}

On dry leaves at Bilthoven (1927).

This seems to be the first record of this species for Europe. The small, brown sporangia were found in a dry ditch under bracken and oak in the "Eykensteinse bossen" near Bilthoven. The collection consists of a dozen sporangia.

The peridium is thin, brown and glossy, and lacks the bright orange tints that are always present in my specimens of Cr. minutum. The spores are somewhat darker and more distinctly violaceous than those of Cr. minutum. 
Craterium leucocephalum (Pers.) Ditmar var. leucocephalum.

On dead leaves and stems of herbs $(373 ; 640 \mathrm{U} ; 713 ; 1385 \mathrm{U}$, Bilthoven; 1462; 1588; 1613; 1636; 4211; 4291; 4295 U; 4405 Ewijk).

The collections are all typical of the species, and as usual in this genus, the spores show but little variability. The plasmodium, where seen, was yellow.

* Craterium leucocephalum (Pers.) Ditmar var. scyphoides Lister.

Collected on dead leaves in a wood adjacent to the "Ridder Robertlaan", Doorwerth (1604; 4175 U; 4227).

Of most of the sporangia of 1604 only the red-brown cups with tattered edges, the spores and the nearly white lime knots are left; a few sporangia, however, are intact, and show the nearly white, farinose upper half. The other specimens are better, and show the diverse stages; in some the pseudo-columella projects in the centre, while the peridium has crumbled away to a lower level. The spores of this variety are larger than those of the typical form, i.e. about 10-11 $\mu$, instead of 7-9 $\mu$, a difference not mentioned in any of the monographs quoted in this paper.

\section{* Craterium cylindricum Massee.}

On a milk bottle cap between dead leaves (2108, leg. J. L. Nannenga).

Lister considered this species to be a variety of Cr. leucocephalum (Pers.) Ditmar. Macbride and Martin (the Myxomycetes, 1931) returned it to its former position, but Martin (North American Flora, 1948) considered it conspecific with $C r$. leucocephalum. As it differs from the latter in the shorter stalk, the smooth peridium, and the paler, more yellowish spores, it seems to me that it deserves to be recognized as a distinct species.

* Graterium auronucleatum nov. spec. maxime ut Cr. leucocephalum ad quod praesertim corpusculis crystallinis luteis peridio et capillitii nodis innatis accedit, sed sporangiis minoribis, turbinatis vel subglobosis, capillitio denso e filamentis gracillimis composito, filamentis nodis calcareis valde ramosis instructis, pseudocolumella clare aurantiaca, sporis colore saturatiore tinctis ab eo distinguenda; typus 4491, lectus prope villem "Kabeljouw" in vico Wolfheze (Fig. 3).

Sporangia gregaria, sessilia vel stipite ad $0.2 \mathrm{~mm}$ longo instructa, stipite incluso $0.4-0.7 \mathrm{~mm}$ alta, $0.3-0.5 \mathrm{~mm}$ diam., quoque sporangio e hypothallo orbiculari oriente. Hypothallus translucens, ad lucem orientem versus visus clare aurantiacus. Stipes, si adest, plicatus, aurantiacus vel brunneus, lucem orientem versus visus semper aurantiacus, sine inclusionibus granulatis. Sporangium (Fig. 3, a and b) subglobosum vel turbinatum, in parte inferiore aurantiacum, in parte superiore nunc saturate et ferventer brunneum, nunc praesentia inclusionum calcalrearum remissius et dilute aurantiacum. Peridium tenue, translucens, fere semper corpuscula crystallina lutea continens et inde nunc totum aurantiacum, nunc in parte inferiore solum 
aurantiacum et in parte superiore ecoloratum; inclusionibus calcareis, si adsunt, in parte superiore solum repertis; dehiscentia (Fig. 3, c) circumscissilis, ut in Craterio leucocephalo cupulam margine plus minusve inaequali instructam relinquens. Capillitium (Fig. 3, d) e filamentis

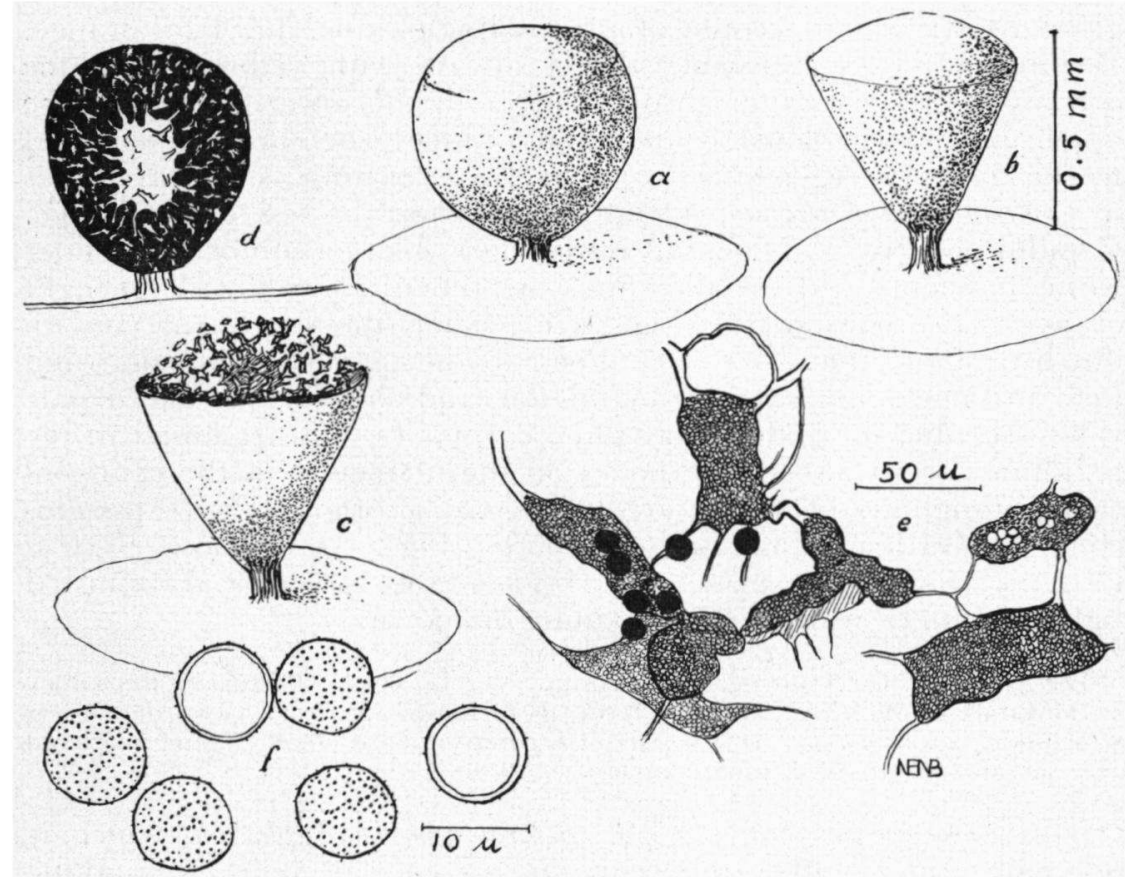

Fig. 3. Craterium auronucleatum nov. spec.: a. and b. sporangia; c. dehisced sporangium; d. sporangium in longitudinal section; e. capillitium nodes and spores; the node on the right showing the yellow corpuscles; f. spores.

gracillimis permultis albis, hic inde nodis parvis albis vel interdum luteolis vel dilute aurantiacis, margine irregulariter in excrescentias graciles productis instructis compositum (Fig. 3, e); nodi si quantitatem calcis parvam continent, margine calce carent, casu quo excrescentiis plerumque luteolis compressis; corpuscula lutea quae peridio intersunt, in nodis etiam occurrunt; in sporangii centro nodi in pseudocolumellam clare aurantiacam, superficie irregularem confluunt. Sporae (Fig. 3, f) globosae, 9-10 $\mu$ diam., per saturam saturate brunneae, ad lucem orientem versus visae saturate violaceobrunneae, minute verruculosae. Plasmodium ignotum.

Habitat rivi vallem prope villam "Kabeljouw" in vico Wolfheze, ubi in area circ. $1 \mathrm{~m}$ in quadrato metiente et e foliis mortuis et $\mathrm{e}$ herba viva consistente plures coloniae parvae repertae sunt (N. E. Nannenga-Bremekamp $4491 \mathrm{U})$.

Sporangia gregarious, sessile or with an up to $0.2 \mathrm{~mm}$ long stipe, with the stipe $0.4-0.7 \mathrm{~mm}$ high and $0.3-0.5 \mathrm{~mm}$ in diam.; each 
sporangium rising from an orbicular hypothallus. Hypothallus transparent, clear orange by transmitted light. Stipe, when present, plicate, orange or brown, translucent orange by transmitted light, without granular inclusions. Sporangium (Fig. 3, a and b) subglobose or turbinate, in the lower part orange, in the upper part either dark glossy brown or, on account of a sprinkling of lime, dull light orange. Peridium thin, transparent, almost always with yellow crystalline corpuscles, either orange throughout or in the lower part only, the upper part being colourless; inclusions of lime, when present, confined to the upper part; dehiscence (Fig. 3, c) circumscissile, leaving, as in Craterium leucocephalum, a cup with a more or less uneven edge. Capillitium (Fig. 3, d) dense, consisting of a large number of slender white filaments with small white, or sometimes yellowish or light orange, calcareous nodes (Fig. 3, e); when the specimens contain but little lime, the latter is confined to the peseudo-columella, and then the nodes are expanded and flat and show, as a rule, a pale yellowish tint; the yellow crystalline corpuscles that are found in the peridium, occur also in the nodes on the filaments; in the centre of the sporangium the nodes are fused into a bright orange pseudocolumella with unequal surface. Spores (Fig. 3, f) globose, 9-10 $\mu$ in diam., dark brown in mass, dark violaceous brown by transmitted light, minutely warted. Plasmodium unknown.

The type (N. E. Nannenga-Bremekamp $4491 \mathrm{U}$ ) was collected in the valley of the brook at Wolfheze near the farm "Kabeljouw" on dead leaves and living grass under a solitary oak. It was part of a group of many small colonies scattered over an area of about 1 square meter $(8.9,1960)$.

This new species comes close to Craterium leucocephalum, which it resembles among other things in the presence of yellow crystalline corpuscles in the peridium and in the capillitium nodes. It differs from that species in the smaller size and the turbinate or subglobose shape of the sporangia, the dense capillitium consisting of very thin threads with many branched lime knots, the brilliant orange pseudocolumella and the darker colour of the spores.

The yellow corpuscles found in the periderm and in the nodes on the capillitium threads were regarded by Lister as a characteristic feature of $\mathrm{Cr}$. leucocephalum and the two varieties of this species distinguished in the monograph, viz. cylindricum and scyphoides.

\section{Craterium aureum (Schum.) Rost.}

In summer on dead leaves and straw, and on living leaves of ivy $(372 ; 382 \mathrm{U}$; $1301 \mathrm{~b} ; 1308 ; 1368 ; 1394 \mathrm{U}$, Bilthoven; $1438 ; 1455 ; 2838 \mathrm{U} ; 2839 ; 2890$, Bilthoven; $2899 ; 2904 ; 2907 ; 2959 ; 3012)$; on fallen bark of apple $(4247$, sporangia somewhat abnormally developed; spores normal).

The sporangia are usually turbinate, and differ therefore from those of * Physarum flavidum (Peck) Peck, with which I have found it growing in mixed clumps. The spores of the latter are, of course, much darker and larger. Those of Cr. aureum are rather uniform. The plasmodium, seen in a number of cases, was yellow. 


\section{Echinostelium De Bary}

\section{* Echinostelium minutum De Bary}

Very common on the bark and wood of dead and living trees. The sporangia are in their natural habitat difficult to see, and were therefore all obtained from moist-chamber cultures from the bark of living trees of Quercus; 3326; $3327 \mathrm{U}$; $3329 ; 3330 ; 3349 ; 3412 ; 2417 ; 3568$, Plasmolen near Nymegen; 3866 U; 3881 ; 3882 ; 3885; 3877; 4092; of Betula: 3712; 3728; 3804; of Prunus laurocerasus: 4131; 4312; of Aesculus: 3863; 3856; of Fagus: 3306; of Larix: 3715 ; from a fallen branch of Tilia: $3664 \mathrm{U}$; 3669; 3671; 3700; from decaying coniferous wood: 3332 ; 3806; $3903 ; 3946 / 3953 ; 4051)$.

When the stalk has been developed, the "plasmodium" shows as a hyaline drop. Most of my specimens are white or nearly so; 3728 , 3885 and 4131 are very pale pink. The spores all measure 6-9 $\mu$, except those of 3306, which are about $12 \mu$ in diameter; those of 3728 and 4092 are very minutely spinulose; those of the other specimens are smooth. They are often provided with slightly thickened "areolae", as described in Lister's "Monograph" and by Alexopoulos (Am. Journ. Bot. 47: 38, Fig. 5). The latter says that this structure of the spore wall is a character confined to the genus Echinostelium.

*Echinostelium fragile nov. spec., maxime ut $E$. minutum De Bary et $E$. elachiston C. J. Alexopoulos, a priori magnitudine triente, ab altero stipite apicem versus contracta, columella conica brunnea et sporis majoribus recedens; typus 3868 , cultus e plasmodio lecto in loco dicto "Hemelse Berg" prope Oosterbeek-Laag, ubi in cortice Aesculi crevit (Fig. 4).

Sporangia sparsa vel gregaria, stipitata, erecta vel nutantia, $0.13-0.15 \mathrm{~mm}$ alta. Stipes apicem versus sensim contractus (Fig. $4 \mathrm{a}$ ), decolor, interdum striatulum, basi substantiam granulosam paucam continens, circ. $90 \mu$ longus. Sporangium globosum, 30-50 $\mu$ diam., dilute rosea vel salmonea, post dies paucos colorem griseo-brunneum sumens; peridium vix distinguendum, evanescens, sed ad apicem stipitis annulum distinctum relinquens; columella (Fig. 4 b) brunnea, fusiformis, circ. $6 \mu$ longa; capillitium nullum; sporae (Fig. $4 \mathrm{c}$ ) subglobosae, per saturam necnon lucem orientem versus visae dilute

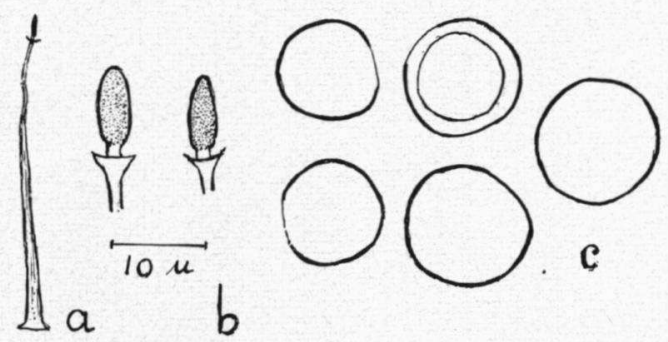

Fig. 4. Echinostelium fragile nov. spec.: a. stipe with peridial collar and columella; b. two columellae enlarged; c. spores (enlarged to the same scale as b); the two spores on the left and the three spores on the right from two different sporangia (both belonging to the type colony); one of the spores in optical section. 
roseae vel griseae, laeves, areola tenuiore $12-(13)-15 \mu$ diam. instructae. Plasmodium hyalinum, dilute roseum.

Habitat provinciam Gelriam ubi in loco dicto "Hemelse Berg" prope vicum Oosterbeek-Laag in cortice Aesculi lectum est.

Sporangia scattered or gregarious, stipitate, erect or nodding, $0.13-0.15 \mathrm{~mm}$ high. Stipe (Fig. 4 a) tapering, colourless, sometimes slightly striate, with a little included matter at the base, about $90 \mu$ long. Sporangium globose, 30-50 $\mu$ in diameter, very pale pink or salmon, turning brownish-grey after a few days; peridium almost invisible, evanescent, leaving a tiny, well-marked collar at the tip of the stipe; columella (Fig. 4 b) brown, fusiform, about $6 \mu$ long; capillitium absent; spores (Fig. 4 c) subglobose, pale pink or grey in mass as well as by transmitted light, smooth, with a small thinner area 12-(13)-15 $\mu$ in diam. Plasmodium hyaline, pale pink.

Netherlands: Province of Gelderland, "Hemelse Berg" near Oosterbeek-Laag (3862; 3867; 3868, type; 3915 ; 3916; plasmodia on the bark of Aesculus; sporangia grown in moist-chamber culture).

This minute species resembles $E$. minutum De Bary in general aspect, especially in the structure and in the shape of the stipe, but it is only about one third as high. Among the specimens quoted above, some sporangia of $E$. minutum itself were also present. It comes apparently also close to $E$. elachiston Alexopoulos, but differs from that species in the tapering stalk, the presence of a brown fusiform columella and the larger size of the spores. The thickenings of the spore wall are absent or so very inconspicuous as to appear so, but this was also observed in some gatherings of $E$. minutum. 'The small sporangia are very difficult to mount, as they become easily detached, probable owing to the absence of a capillitium. This applies also to the sporangia of $E$. elachiston. 